\title{
Delivering emergency and trauma care in Sri Lanka in 2017 - A decade of change and leadership by the Emergency Treatment Unit of Teaching Hospital Karapitiya
}

\author{
O'Reilly G M ${ }^{1,2,3}$, Fitzgerald M C 1,3,4, Ariyananda P L5 , Williams $\mathbf{S}^{6}$, Jayasekera $\mathrm{K}^{7}$, Munasinghe A K , \\ Uluwattage $\mathbf{W} \mathbf{H}^{7}$, Seneviratne $\mathbf{R}^{7}$, Pathmawathie I G ${ }^{7}$, Charlton $\mathbf{S}^{2,9}$, Chou $\mathbf{K}^{2,10}$, Mathew $\mathbf{J}^{1,2,4}$, Smit D V $\mathbf{~}^{1,2,3}$, \\ Cameron $\mathbf{P} \mathbf{A}^{1,2,3}$
}

Journal of the Ceylon College of Physicians, 2017, 48, 15-19

\section{Summary}

Following the 2004 tsunami in Sri Lanka, the Health for the South Project was initiated by the Sri Lankan Ministry of Health, Teaching Hospital Karapitiya in Galle, and the Government of Victoria. With support from the Australian and Victorian Governments, the Alfred Hospital delivered the Capacity Building Component. The aim of the overall Project was to construct a fully equipped and staffed Emergency Trauma Centre; the aim of the Capacity Building Component was to increase the capacity of Teaching Hospital Karapitiya staff to deliver effective emergency and trauma care. The program included training in the systematic and team approach to trauma care plus triage, trauma quality improvement and disaster response. Following the formal completion of the Project, local medical and nursing champions have continued to improve the level of emergency and trauma care provided by Teaching Hospital Karapitiya; the facility is now a national and regional leader in the training and delivery of excellent emergency and trauma care.

${ }^{1}$ National Trauma Research Institute, The Alfred Hospital, Melbourne, Australia.

2 Emergency and Trauma Centre, The Alfred Hospital, Melbourne, Australia.

${ }^{3}$ Monash University, Melbourne, Australia.

${ }^{4}$ Trauma Service, The Alfred Hospital, Melbourne, Australia.

${ }^{5}$ Department of Internal Medicine, International Medical University, Malaysia.

${ }^{6}$ Department of Premier and Cabinet, Government of Victoria, Australia.

7 Teaching Hospital Karapitiya, Galle, Sri Lanka.

${ }^{8}$ Accident and Emergency Department, Base Hospital, Kiribathgoda, Sri Lanka.

9 Emergency Department, Monash Medical Centre, Victoria, Australia.

${ }^{10}$ Emergency Department, Box Hill Hospital, Victoria, Australia.

Corresponding author: O'Reilly GM

E-mail: gerard.oreilly@monash.edu

\section{Background}

Globally, the burden of injury is enormous and increasing ${ }^{1}$. In Sri Lanka, in the decade preceding the Indian Ocean tsunami of 26 December 2004, injury had become the major cause of hospitalisation and the second most common cause of death (after cardiovascular disease) 2,3,4. The tsunami killed 35,322 people, and injured an additional 21,411 survivors across Sri Lanka ${ }^{5}$. Galle, the main city in the south of the country, suffered a considerable proportion of the human loss ${ }^{5}$. Teaching Hospital Karapitiya (THK) was the focal point of the local medical response immediately following the tsunami.

In response to the tsunami in Sri Lanka, multiple international organisations provided support across multiple sectors, including health. The local health provider community identified that to improve disaster response requires optimising disaster resilience ${ }^{5,6}$. Disaster resilience, in turn, requires the strengthening of emergency and trauma care systems ${ }^{5,6}$. Consequently, the Government of the State of Victoria, Australia, in partnership with the Sri Lankan Ministry of Health, embarked on the Health for the South Project.

The aim of the Health for the South Project was to improve the capacity of trauma and emergency care (and therefore disaster preparedness) in the south of Sri Lanka, through the construction of a new comprehensive and suitably equipped and staffed Emergency Trauma Centre (ETC). Given that integrated emergency and trauma care systems were not developed in Sri Lanka at the time, similar to many other countries, a concurrent Capacity Building Component of the Project was conceived for the provision of emergency and trauma care training to the staff; this component was delivered by staff from the Alfred and the Royal Children's Hospitals, Melbourne, Australia ${ }^{6-11}$.

The aim of this perspective is to describe the major developments in trauma and emergency care at THK between the post-tsunami recovery period and the end of 2016. The focus is on programs linked to the Health for the South Project - Capacity Building Component.

http://orcid.org/0000-0001-5763-917X

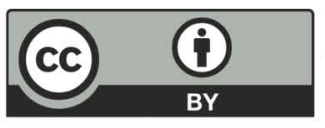

This is an open-access article distributed under the terms of the Creative Commons Attribution License, which permits unrestricted use, distribution, and reproduction in any medium, provided the original author and source are credited. 


\section{Methods - Program Delivery}

The details of the series of programs delivered for, or linked to, the Capacity Building component of the Health for the South Project are provided in Table 1. An overall outline of the program is provided here. Following a 2005 on-site assessment by senior Alfred Hospital medical staff (MCF, JM) of the existing situation for emergency and trauma care at THK, the following list of recommended priorities was provided to THK, the Ministry of Health and the Victorian Government (MCF, GMO, PLA) ${ }^{4,12}$ :

1. An interim, reconstructed Emergency Treatment Unit in the existing outpatient building

2. Equipment

3. Training

4. Institution of an objective triage system and combined medical / nursing record

5. A new Emergency Department adjacent to the current Out-patient building

The priority of the recommendations was to augment interim capacity (space, equipment, staff skills) in order to deliver high level emergency trauma care during the planned construction period of the new 3-storey Emergency Trauma Centre ${ }^{4,12}$. Subsequently, with the support of Irish NGO (GOAL) and USAID, the basic 2-bed emergency room was expanded to a 6-bed Emergency Treatment Unit (ETU) with the necessary trolleys, ventilators, cardiac monitors, portable XRay machine and teaching aids (mannequins).

The Capacity Building Component of the Health for the South Project formally commenced one decade ago in early 2007 and was supported by both Australian (AusAID) and Victorian Government funding. The content of the Phases of the project are detailed in Table 1, and summarised below.

For Phase 1 (Capacity Building Component), the teams consisted of Alfred Hospital emergency physicians and senior critical care trained emergency nurses. Five trauma and emergency training modules, including triage training, were each delivered over a four-week period, with a focus on clinical bed-side training. A longstanding feature of the Trauma Team Training (TTT) program (delivered by the Alfred in Sri Lanka, India, Myanmar, The Philippines and China) is the recognition that emergency trauma care demands an integrated team (doctor and nurse) approach; during the program, doctor and nurse participants work together at practically all times, as do the doctor and nurse faculty ${ }^{13}$.
For Phase 2 (Trauma System Maturation Component), the content and faculty for the program was similar, but with additional consultancy, focus groups and workshops engaging the key stakeholder trauma and emergency care providers across THK. With an added focus on the intra-hospital system-wide Model of Care, this phase was intentionally designed to bridge the transition from the 6 bed ETU to the 30-plus bed ETU (including 4 comprehensive resuscitation bays) of the newly constructed ETC. The ETC was officially opened in March 2011, at which time the care of emergency patients at THK was transferred to the new ETU.

For Phase 3 (Trauma System Mentoring Component), the content and faculty, in addition to further TTT program delivery, were tailored to consolidating and optimising the planned Model of Care across the new ETC. By the commencement of this Phase in July 2012, all three floors of the ETC were treating patients, including the ETU with co-located Radiology service on Ground Floor, the 4 Operating Theatres and Intensive Care Unit on First Floor, and the Short Stay Unit on Second Floor. Areas of focus for this phase included patient flow, admission protocols, managing all unexpected presentations, disaster planning, and quality improvement $\operatorname{activities}^{14,15}$

In addition to the 3 clear in-country phases of the Capacity Building Component, there were a series of additional activities which complemented the Health for the South Project. Firstly, during each phase, key local trauma and emergency care stakeholders undertook observational training visits to the Alfred Hospital, for 2 to 3 weeks at a time. The Australian Government (AusAID) also funded a 3-month leadership training period for a senior THK emergency nurse at the Alfred Hospital. Finally, as part of the Australian Government South Asia Trauma Team Training (TTT) Project, four key local (Galle and Kandy) champion emergency staff (medical and nursing) attended TTT training in Ludhiana, Punjab, India, before being subsequently mentored as emergency and trauma care trainers back in Sri Lanka ${ }^{13}$.

\section{Results - Program Outputs}

Regular and detailed pre- and post-program monitoring and evaluation was conducted across the whole of the Capacity-Building Component (7 years) of the Health for the South Project, the results of which have been detailed elsewhere ${ }^{4,16}$. A summary of the key developments, which reflect the gaps and objectives identified at the commencement of the program, are as follows ${ }^{17}$ : 
Table 1. Programs linked to the Capacity-Building Component of the Health for the South Project

\begin{tabular}{|c|c|c|c|c|}
\hline Program Dates & Program Title & Program Aims & Program Content & $\begin{array}{l}\text { Program faculty } \\
\text { (International to } \\
\text { Sri Lanka) }\end{array}$ \\
\hline $\begin{array}{l}\text { February } 2007 \\
\text { to June } 2008\end{array}$ & $\begin{array}{l}\text { Capacity-Building } \\
\text { Program }\end{array}$ & $\begin{array}{l}\text { - Systematic approach to } \\
\text { the resuscitation of the } \\
\text { critically injured or } \\
\text { ill patient } \\
\text { - Team approach to } \\
\text { trauma resuscitation } \\
\text { - Triage } \\
\text { - Disaster preparedness }\end{array}$ & $\begin{array}{l}\text { - Five 4-week training } \\
\text { modules at THK } \\
\text { - } 1 \text { week: APLS Course (led } \\
\text { by Royal Children's } \\
\text { Hospital, Melbourne) } \\
\text { - Two 3-week } \\
\text { observational training } \\
\text { periods for } 4 \text { THK staff } \\
\text { to Alfred Hospital }\end{array}$ & $\begin{array}{l}\text { - } 8 \text { emergency } \\
\text { physicians } \\
\text { - } 14 \text { emergency } \\
\text { nurses }\end{array}$ \\
\hline $\begin{array}{l}\text { September } 2008 \\
\text { to January } 2009\end{array}$ & $\begin{array}{l}\text { Australian Leader- } \\
\text { ship Award }\end{array}$ & $\begin{array}{l}\text { - Develop a triage } \\
\text { system for THK } \\
\text { - } \\
\text { Develop a Disaster } \\
\text { Plan for THK }\end{array}$ & $\begin{array}{l}\text { - 3-month training } \\
\text { program at Alfred } \\
\text { Hospital for senior THK } \\
\text { emergency nurse }\end{array}$ & Not applicable \\
\hline $\begin{array}{l}\text { July } 2009 \\
\text { to December } 2009\end{array}$ & $\begin{array}{l}\text { South Asia Trauma } \\
\text { Team Training (TTT) } \\
\text { Program }\end{array}$ & $\begin{array}{l}\text { - Systematic approach to } \\
\text { the resuscitation of the } \\
\text { critically injured or ill } \\
\text { patient } \\
\text { - Team approach to } \\
\text { trauma resuscitation } \\
\text { - Triage } \\
\text { - Disaster preparedness }\end{array}$ & $\begin{array}{l}\text { - 3-week Trauma Team } \\
\text { Training (TTT) program } \\
\text { in Ludhiana, India } \\
\text { (including Train the } \\
\text { Trainer program for } 4 \\
\text { Sri Lankan faculty) } \\
\text { - } 1 \text { week follow-up Train- } \\
\text { the-Trainer mentorship } \\
\text { in Galle and Kandy }\end{array}$ & $\begin{array}{l}\text { - } 9 \text { emergency } \\
\text { physicians } \\
\text { - } 7 \text { emergency } \\
\text { nurses }\end{array}$ \\
\hline $\begin{array}{l}\text { June } 2010 \\
\text { to March } 2011\end{array}$ & $\begin{array}{l}\text { Trauma System } \\
\text { Maturation Compo- } \\
\text { nent }\end{array}$ & $\begin{array}{l}\text { - To develop a capacity } \\
\text { consistent with WHO } \\
\text { criteria for a Level } 1 \\
\text { Trauma Centre. } \\
\text { - Undergo a smooth } \\
\text { transition to the } \\
\text { newly completed ETC } \\
\text { - Develop protocols for } \\
\text { patient admission and } \\
\text { discharge in the ETC }\end{array}$ & $\begin{array}{l}\text { - One week Workshop on } \\
\text { Model of Care post- } \\
\text { completion of ETC } \\
\text { - Three 2-week Trauma } \\
\text { Team Training (TTT) } \\
\text { program revision } \\
\text { modules } \\
\text { - Triage training revision }\end{array}$ & $\begin{array}{l}\text { - } 7 \text { emergency } \\
\text { physicians } \\
\text { - } 8 \text { emergency } \\
\text { nurses }\end{array}$ \\
\hline $\begin{array}{l}\text { July } 2012 \text { to June } \\
2013\end{array}$ & $\begin{array}{l}\text { Trauma System } \\
\text { Mentoring Compo- } \\
\text { nent }\end{array}$ & $\begin{array}{l}\text { - Completion of } \\
\text { functional goals for ETC } \\
\text { - Trauma Quality } \\
\text { Improvement Program } \\
\text { training } \\
\text { - Disaster plan revision } \\
\text { and training }\end{array}$ & $\begin{array}{l}\text { - One week Workshop on } \\
\text { Model of Care for new } \\
\text { ETC } \\
\text { - Two 3-week Clinical } \\
\text { Teaching Modules } \\
\text { across new ETC } \\
\text { - 2-week observational } \\
\text { training visit of } 3 \text { senior } \\
\text { THK staff to Alfred } \\
\text { Hospital } \\
\text { - 2-day Workshop on } \\
\text { WHO Trauma Quality } \\
\text { Improvement Program } \\
\text { guidelines }\end{array}$ & $\begin{array}{l}\text { - } 1 \text { senior } \\
\text { Hospital } \\
\text { - Administrator } \\
\text { - } 7 \text { emergency } \\
\text { physicians } \\
\text { - } 4 \text { emergency } \\
\text { nurses } \\
\text { - } 1 \text { intensivist } \\
\text { - } 2 \text { intensive } \\
\text { care nurses } \\
\text { - } 2 \text { anaesthe- } \\
\text { tists } \\
\text { - } 1 \text { trauma } \\
\text { ward nurse }\end{array}$ \\
\hline
\end{tabular}




\section{Systematic approach to trauma care}

The timely sequential assessment and management (and repeated re-evaluation) of immediately lifethreatening injuries was delivered by THK emergency doctors and nurses. The same principles of resuscitation are readily transferable to emergency care in the noninjured patient.

\section{Triage}

Triage, based on a locally developed scale, was delivered safely, effectively and in a timely fashion by senior emergency nurses with strong medical and administrative support.

\section{Documentation}

The real-time, routine, frequent and regular documentation of vital signs (including Glasgow Coma Score), pain, and the assessment findings established and procedures conducted during the resuscitation setting (e.g. cardiac arrest or endotracheal intubation), was implemented.

\section{Teamwork}

Teamwork requires a mutual understanding of, and respect for, both medical and nursing roles in the emergency department environment, including in the setting of patient resuscitation. It demands effective leadership and communication, which was achieved by the THK ETU staff.

\section{Specific}

Further to the augmentation of general processes of trauma and emergency care over the period of the Health for the South Project, attention to specific interventions and procedures increased, consistent with the maturation of Emergency Medicine in Sri Lanka. These included: administration of high flow oxygen (e.g. in the major trauma patient), continuous cardiac monitoring, analgesia delivery, the safe transport of the critically injured or ill patient (e.g. to CT scan), spinal precautions, rapid sequence intubation (for endotracheal intubation of the non-arrested patient) and insertion of intercostal catheter (for haemopneumothorax following chest trauma).

Although the formal period of the Health for the South Project: Capacity-Building Component finished in 2013, the high level of trauma and emergency care delivered in the THK ETU has been further augmented. Additional ETU-based interventions, initiated and driven by local champions over the last decade, to great effect for patient outcomes, included the following:
1. The liberal use of non-invasive ventilation

2. Thrombolysis (for ST elevation myocardial infarction and acute strokes)

3. Diagnostic ultrasound (in trauma and non-trauma patients)

4. Commencement of a Quality Improvement Program, including Mortality and Morbidity meetings.

The positive impact of emergency care capacity-building has been evident across the ETC and the rest of THK, including the following:

1. ETU-led training of medical and nursing staff

2. Improvements in the quality of patient care (monitoring and treatment) seen on inpatient wards

3. Formal university-rotations of medical students through the ETU

4. Exposure of medical and nursing undergraduates and medical postgraduates (other than emergency medicine trainees) to improved standards and timeliness of emergency care during placements and visits to the ETU ${ }^{17}$.

THK's provision of integrated emergency and trauma care has made it a national leader. It is the model upon which the government's comprehensive planning for ETUs across Sri Lanka is based. It is currently a peak rotation for emergency medicine specialty trainees, the first batch of which completed their final MD Emergency Medicine (EM) examinations in September $2016^{18}$. The THK ETU uses an innovative model of nurse-delivered triage.THK staff have provided emergency, trauma and triage training for health providers across Sri Lanka and internationally, with overseas emergency physicians and nurses contributing time to assist with local EM training and mentorship ${ }^{19}$.

\section{Discussion}

THK ETU now provides emergency and trauma at an international standard. Over the decade since the formal commencement of the Health for the South Project, there have been several lessons learnt which are relevant to the evolution of emergency and trauma care across the rest of Sri Lanka, and the many settings of Asia where it is developing.

Firstly, the engagement of local stakeholders is key. Improvements in emergency care places an increased demand upon other departments - especially other areas in a hospital which also need to deal with critical care patients in a timely way (e.g. ICU, operating theatre). In addition to medical and nursing champions of emergency and trauma care, other critical stakeholders (e.g. Internal Medicine, Paediatrics, Anaesthetics, ICU, Surgery), have been very supportive of EM. There is now a good 
understanding of the specialty amongst senior hospital administrators and Ministry officials.

Secondly, the requirements of a team-based patientcentred approach in the ETU demands a momentum for change from the grassroots. Whilst senior medical champions are very important in directing change, generating and sustaining the necessary changes in patient-level emergency care requires trained and enthusiastic senior emergency nursing staff ${ }^{19}$. Documentation, clinical protocols, patient flow, triage, analgesia, universal precautions, training and quality improvement activities are all domains which can be emergency nurse led ${ }^{19}$.

\section{Conclusion}

Over the last decade, beginning with the Health for the South Project, the THK ETU has evolved into a leading national and international example of trauma and emergency care. THK ETU has benefited from local, national and internationalleadership to become a model for excellence in trauma and emergency care.

\section{Acknowledgements}

The authors wish to acknowledge the longstanding and significant support for and contribution to the Health for the South Project by the Ministry of Health in Sri Lanka, the Australian Government, the Government of Victoria, and the many participating staff from the Alfred Hospital, Melbourne and Teaching Hospital Karapitiya, Galle. The major trauma and emergency care steps of THK over the last decade could not have been achieved without the enthusiasm, hard work and persistence of the Sri Lankan senior health care providers and advocates both in Galle and across the country.

\section{References}

1. Naghavi M, Wang H, Lozano R, et al. Global, regional, and national age-sex specifically - cause and causespecific mortality for 240 causes of death,1990-2013: a systematic analysis for the Global Burden of Disease. Lancet 2015; 385:117-71.

2. Medical Statistics Unit, Ministry of Healthcare \& Nutrition, Sri Lanka. Sri Lanka: Health at a Glance. Volume 1, 2008. Available from www.statistics.gov.lk/Newsletters/Health \%20Bulletin(Medical\%20Stat).pdf. (Accessed 20 January 2017)

3. Vithana C, Linhart C, Taylor R, Morrell S, Azim S. Trends in Sri Lankan cause-specific adult mortality 1950-2006. BMC Public Health 2014; 14: 644.

4. O'Reilly G, Fitzgerald M, Ariyananda PL, Williams S, et al. Beyond the wave: The Sri Lanka Health for the South Project. Emergency Medicine Australasia 2008; 20: 175-9.
5. TAFREN (Task Force to Rebuild the Nation). Post Tsunami Recovery and Reconstruction Joint Report of the Government of Sri Lanka and Development Partners, December 2005. Available from http://www. preventionweb. net/publications/view/2180 (Accessed 20 January 2017).

6. United Nations Development Program. Human Development Report 2014. Sustaining human progress: reducing vulnerabilities and building resilience. Available from: http:/ /hdr.undp.org/sites/default/files/hdr14-report-en-1.pdf [Accessed 20 January 2017].

7. Atkin C, Freedman I, Rosenfeld JV, et al. The evolution of an integrated state trauma systems in Victoria, Australia. Injury 2005; 36: 1277-87.

8. Cameron PA, Gabbe B, Cooper DJ, et al. A statewide system of trauma care in Victoria: effect on patient survival. Med J Aust 2008; 189: 546-50.

9. Gabbe BJ, Simpson PM, Sutherland AM, et al. Improved functional outcomes for major trauma patients in a regionalized, inclusive trauma system. Ann Surg 2012; 255(6): 1009-15.

10. Mock C, Lormand JD, Goosen J, et al (editors). Guidelines for essential trauma care. Geneva: World Health Organization, 2014.

11. Fitzgerald M, Dewan Y, O'Reilly, Matthew J, McKenna C. India and the Management of Road Crashes: Towards a National Trauma System. Indian J Surg 2006; 68(4): 237-43.

12. Fitzgerald M. The development of emergency services at Karapitiya Hospital, Galle, Sri Lanka, post tsunami. Report to the Department of Premier and Cabinet, State Government of Victoria and World Vision Australia, Melbourne. 2005.

13. O'Reilly GM, Fitzgerald M, Dewan Y, Chou K, Mathew J, Peters N. The Alfred Trauma Team Training program in India and Sri Lanka. Emerg Med Australas 2011; 23: 632-9.

14. Mock C, Juillard C, Brundage S, et al (editors). Guidelines for trauma quality improvement programmes. Geneva: World Health Organization, 2009.

15. Stelfox $H T$, Joshipura $M$, Chadbunchachai W, et al. Trauma quality improvement of low-and middle-income countries in the Asia-Pacific region: A mixed methods study. World J Surg 2012; 36: 1978-91.

16. O'Reilly G, Fitzgerald M, Ariyananda PL, Jayasekera K, Williams S, Charlton $S$, et al. Trauma reception and resuscitation in Sri Lanka: the Health for the South Capacity-Building Project. Emerg. Med. Australas 2009; 21: $147-52$

17. Ariyananda PL, Jayasekera K. Recent developments in infrastructure and capacity building at the Teaching Hospital, Karapitiya (THK), Sri Lanka towards improving care given to patients with trauma and emergencies. Galle Medical Journal 2009; 14 (1): 1-4.

18. Tan G, Gunasekera C, Curran S. Emergency Medicine in Sri Lanka: The inevitable solution to a new specialty. Emerg. Med Australas 2008; 20: 81-4.

19. Charlton S, O'Reilly GM, Jones T, Fitzgerald M. Emergency care in developing nations: The role of emergency nurses in Galle, Sri Lanka. Australasian Emergency Nursing Journal 2011; 14(2): 69-74. 